\title{
Analisis Penerapan Enterprise Resource Planning (ERP) Pada PT Sinar Sosro Palembang
}

\author{
Ria Andika \& Diana \\ Fakultas Ilmu Komputer, Universitas Bina Darma \\ Email: andikaria09@gmail.com,@binadarma.ac.id
}

\begin{abstract}
PT. Sinar Sosro which is the first ready to drink bottled company in Indonesia and in the world. In developing its business, PT. Sinar Sosro has distributed sales throughout the archipelago, through sales branch offices spread throughout the archipelago. PT. Sinar Sosro in its company management has implemented the Enterprise Resource Planning System, the ERP system built by Sosro's management allows access to data from Sosro's branch offices. Functional area at PT. Sinar Sosro covers: Sales and marketing, Manufacturing, Finance, Accounting, Logistics, Distribution, Inventory, Invoice. In the grip of this functional area, PT. Sinar Sosro uses SAP as its ERP program. The distribution system is capable of handling the company's manufacturing, logistics, inventory, shipping, invoicing, and accounting processes. This system helps control business activities such as sales, delivery, production, inventory management, quality management, and human resources. The modules used in SAP are inventory management, plant maintenance, production, finance and accounting, human resource management.
\end{abstract}

Keywords: System, Information, Enterprise Resource Planning.

\section{Pendahuluan}

Enterprise Resource Planning (ERP) adalah system perangkat lunak modular yang dirancang untuk mengintegrasikan area fungsional utama dari proses bisnis perusahaan ke dalam satu sistem yang terpadu. ERP men-standardisasi, menyederhanakan, dan mengintegrasikan proses bisnis seperti keuangan, sumber daya manusia, pengadaan, distribusi, dan departemen lainnya [1]. ERP (Enterprise Resource Planning) adalah multi-modul, solusi aplikasi pengemasan bisnis yang memungkinkan organisasi untuk mengintegrasikan proses bisnis dan kinerja perusahaan, pendistribusian data umum, pengelolaan sumber daya serta menyediakan akses informas secara actual [2]. ERP (Enterprise Resource Planning) adalah software lintas fungsi terpadu yang merekayasa ulang proses manufaktur, distribusi, keuangan, sumber daya manusia, dan proses bisnis lainnya dari suatu perusahaan untuk memperbaiki efisiensi, kelincahan, dan profitabilitasnya[3]. Enterprise Resource planning merupakan suatu metode bagi industri dalam mengupayakan proses bisnis yang lebih efisien dengan membagi informasi di dalam dan antar bisnis proses dan menjalankan bisnis secara elektronik [4].

Salah satu perusahaan industry yang sudah memiliki ERP yakni PT Sinar Sosro yang merupakan perusahaan teh siap minum dalam kemasan botol yang pertama di Indonesia dan di dunia. Dalam pengembangan bisnisnya,PT.Sinar Sosro telah mendistribusikan produknya keseluruh Nusantara,melalui kantor cabang Penjualan yang tersebar di seluruh Nusantara,salah satu cabang PT. Sinar Sosro ada di kota Palembang yang beralamat di Jl. Camat I Km 17 Sukajadi II Talang Kelapa, Banyuasin, Palembang Sumatera Selatan.

Penggunaan ERP menjadikan semua sistem di dalam suatu perusahaan menjadi satu sistem yang terintegrasi dengan satu database, sehingga beberapa departemen menjadi 
lebih mudah dalam berbagi data, dan lebih mudah pula dalam melakukan komunikasi[5]. Enterprise Resource Planning (ERP) dapat mengintegrasikan fungsi marketing, fungsi produksi, fungsi logistik, fungsi finance, fungsi sumber daya manusia, dan fungsi lainnya[6]. ERP pada PT. Sinar Sosro dalam menanajemen perusahaannya. Sistem ERP yang dibangun manajemen Sosro ini memungkinkan akses data dari kantor cabang Sosro. Sistem ini mampu menangani proses manufaktur, logistik, distribusi, persediaan (inventory), pengapalan, invoice, dan akuntansi perusahaan. Sistem ini juga membantu mengontrol aktivitas bisnis seperti penjualan, pengiriman, produksi, manajemen persediaan, manajemen kualitas, dan sumber daya manusia. Module-module yang digunakan dalam SAP adalah inventory management,plant maintenance,production,financial and accounting,human resources management.

\section{Tinjauan Literatur}

\subsection{Enterprise Resource Planning}

Menurut Hau dan Kuzic (2010), ERP (Enterprise Resource Planning) adalah multimodul, solusi aplikasi pengemasan bisnis yang memungkinkan organisasi untuk mengintegrasikan proses bisnis dan kinerja perusahaan, pendistribusian data.

\subsubsection{Manfaat Pengguanaan ERP Pada PT. Sinar Sosro}

Manfaat yang diperoleh dari penggunaan ERP0bagi PT. Sinar Sosro adalah :

a. Meningkatkan efisiensi dalam proses bisnis misalnya dalam fungsi akuntansi yaitu mempermudah dalam tutupbuku

b. Mempermudah pengambilan keputusan bisnis, dikarenakan data yang selalu terupdate, akurat dan konsisten.

c. Efisiensi penggunaan jumlah pegawai.

d. Mempermudah kontrol perusahaan

e. Penyeragaman kebijakan diantara semua unit bisnis perusahaan

\subsection{System Application and Product in data processing (SAP)}

SAP merupakan sistem software ERP yang di dalamnya terintegrasi prosesproses bisnis seperti bagian production, material, warehouse, human resources, sales and distribution, finance, dan lain-lain. SAP diproduksi oleh perusahaan SAP AG. SAP AG adalah perusahaan software antar perusahaan yang terbesar di dunia dan secara keseluruhan pemasok software independen terbesar keempat di dunia dengan visi perusahaan "our vision for companies of all sizes to become best run businesses" Best run businesses transform rigid value chains into dynamic business networks of customers, partners, and supplier.

\section{Metode Penelitian}

\subsection{Jenis Penelitian}

Penelitian ini menggunakan pendekatan deskriftif dengan metode kualitatif. berpendapat bahwa metode deskriftif adalah` suatu metode dalam penelitian suatu kelompok manusia, suatu objek, suatu kondisi, suatu system pemikiran, ataupun suatu kelas peristiwa pada masa sekarang [7]. Penelitian deskriptif adalah penelitian yang dimaksudkan untuk menyelidiki keadaan, kondisi atau hal lain-lain yang sudah disebutkan hasilnya dan dipaparkan dalam bentuk laporan penelitian[8].penelitian deskriptif adalah suatu bentuk 
penelitian yang ditujukan untuk mendeskripsikan fenomena-fenomena yang ada, Fenomena itu bisa berupa bentuk, aktivitas, karakteristik, perubahan, hubungan, kesamaan, dan perbedaan antara fenomena yang satu dengan fenomena lainnya [9].

\subsection{Tahap Penelitian}

Proses-proses analisis kualitatif yang digunakan dalam penelitian ini dikenal dengan analisis spiral dan dijabarkan ke dalam empat langkah berikut ini [10].

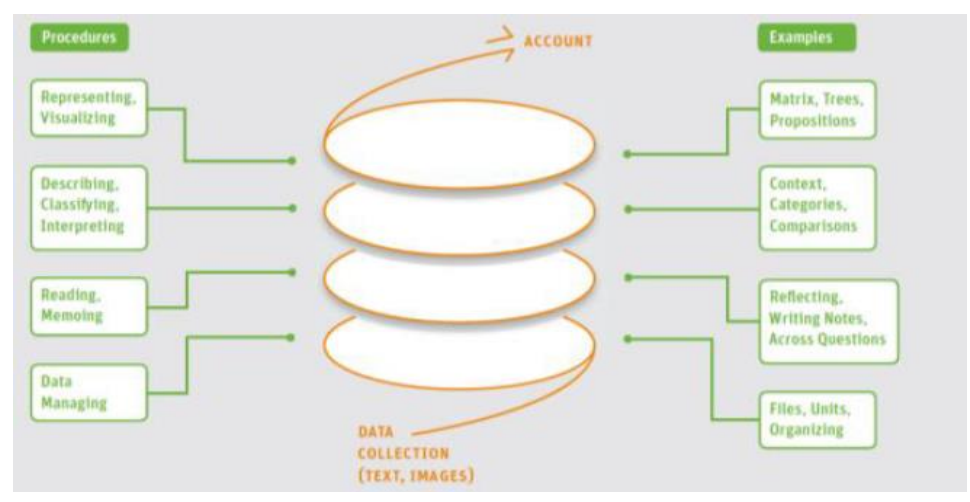

Gambar 1. Analisis Data Spiral

1. Data Managing. Putaran pertama dalam spiral, peneliti mengelola data yang dibutuhkan danmengubah data menjadi sesuai teks yang dibutuhkan. Data ini berasal dari wawancara dengan teknisi TI, wawancara dengan user, dan laporan PT. Sinar Sosro.

2. Reading Memoring. Peneliti selanjutnya membaca dan memberikan memo untuk mempermudah mengenali data.

3. Describing, Classifying, Interpreting. Pada putaran ini, peneliti menggambarkan, mengelompokkan, dan menafsirkan data secara lebih spesifi sesuai dengan apa yang dilihat di lapangan.

4. Representing, Visualizing. Fase terakhir dalam spiral, peneliti menyampaikan data dalam bentuk teks, atau dalam bentuk angka. Peneliti memberikan rekomendasi yang sesuai dengan permasalahan yang terjadi di perusahaan.

5. Proposisi. Hasil dari penelitian ini adalah berupa proposisi atau dugaan.

\section{Hasil dan Pembahasan}

\subsection{Data managing}

Berdasarkan data yang diperoleh dari PT. Sinar Sosro melalui proses wawancara dan dokumentasi, peneliti mengelompokkan data-data yang dibutuhkan untuk mendapatkan informasi mengenai penerapan Enterprise Resource Planning di PT. Sinar Sosro. Pengelompokan tersebut terdiri dari:

\subsubsection{Informasi mengenai penerapan ERP terdiri 4 tahap awal}

1. Tahap Studi Kelayakan

2. Tahap Mapping Pelaksanaan

3. Tahap Pelaksanaan

4. Tahap Evaluasi 
4.1.2 Informasi mengenai penerapan ERP pada tiap-tiap bagian

1. General Manager

2. Bagian Quality Control

3. Bagian Produksi dan Maintenance (PM)

4. Bagian Personalia dan Umum

5. Bagian Accounting dan Finance

6. Bagian Pembelian

7. Bagian Divisi/Supervisor

8. Bagian Gudang Persediaan

4.1.3 Informasi mengenai modul ERP yang digunakan.

Berikut ini adalah beberapa modul ERP yang digunakan pada PT Sinar Sosro, terdapat 13 Modul yang digunakan pada tiap-tiap bagian.

1. Logistics
a. Sales and istribution (SD)
b. Material Management (MM)
c. Warehouse Management (WM)
d. Production Planning (PP)
e. General Logistics (LO)
f. Quality Management (QM)

2. Financial
a. Financial Accounting (FI)
b. Controlling $(\mathrm{CO})$
c. Enterprise Controlling (EC)
d. Investment Management (IM)
e. Treasury (TR)

3. Human Resources
a. Personnel Administration (PA)
b. Personnel Development (PD)

PT. Sinar Sosro tidak menggunakan semua modul yang disediakan oleh sistem ERP tersebut karena harga dari modul-modul tersebut yang relatif mahal. Selain mahal, beberapa modul ERP tidak digunakan karena tidak sesuai dengan gerak bisnis perusahaan. Berikut modul ERP yang tidak digunakan perusahaan.

1. Logistics Execution (LE)

2. Plant Maintenance(PM)

3. Project System (PS)

\subsection{Reading, Memoing}

Penerapan ERP pada PT. Sinar Sosro terdiri dari empat proses awal, yaitu:

\subsubsection{Studi Kelayakan}

Studi kelayakan mer pakan proses menganalisis masalah yang akan diteliti dengan suatu tinjauan mengenai faktor-faktor utama yang akan mempengaruhi kemampuan sistem untuk mencapai tujuan yang di inginkan. Dengan demikian sistem yang dikembangkan pada penelitian ini dinilai kelayakan teknis,ekonomis, dan operasional. 
1. Kelayakan Teknis

Dari segi kelayakan teknis, PT. Sinar Sosro mempunyai sumber daya teknis yang dapat mendukung didalam mengimplementasikan sistem ini. Hal ini ditinjau dari ketersediaan dari perangkat keras (hardware) dan perangkat lunak (software) yang mudah didapat, sehingga operasional sistem ERP akan dapat berjalan lancar.

\section{Kelayakan Ekonomis}

Pembuatan dari sistem ERP ini mampu memberikan manfaat bagi PT. Sinar Sosro yaitu dapat memberikan kemudahan, hemat waktu dan penghematan biaya, dalam mengelola data secara efesien antar tiap-tiap bagian.

\section{Kelayakan perasional}

Implementasi sistem ERP membutuhkan proses persiapan yang panjang, perusahaan harus mendatangkan konsultan berpengalaman dari luar perusahaan untuk melakukan studi kelayakan. Konsultan akan melatih karyawan yang disebut dengan BPO (Business Process Outsourching). Setelah BPO mampu mengoperasikan aplikasi ERP, BPO akan melatih karyawan-karyawan antar tiap-tiap bagian yang akan menjadi user aplikasi sistem ERP.

\subsection{Evaluasi}

Pada tahap ini manajemen bersama konsultan akan mengevaluasi pelaksanaan sistem ERP di PT. Sinar Sosro. Evaluasi yang dilakukan meliputi evaluasi sistem dan juga evaluasi kepada user. Adapun penjelasan mengenai penerapan ERP dari masing-masing divisi kerja adalah sebagai berikut:

1. Penerapan ERP bagian General Manager

Bagian General Manager dalam menggunakan SAP R/3 pada Modul Personnel Administration (PA), Personnel Development (PD) yaitu Menentukan garis kebijakan umum dari program kerja perusahaan, Mengarahkan dan meneliti kegiatan perusahaan serta melakukan pengawasan terhadap program kerja, Melaksanakan kontrak kerja dengan pihak luar, Mengkoordinir dan mengawasi tugas-tugas yang didelegasikan kepada manager dan menjalin hubungan kerja yang baik.

2. Penerapan ERP pada Bagian Quality Control

Bagian Quality Control dalam menggunakan SAP R/3 pada modul Material Management (MM) yaitu Mengkoordinir dan mengawasi pengendalian mengenai mutu produk dan keadaan mesin/peralatan yang digunakan dalam proses produksi.

3. Penerapan ERP pada Bagian Produksi dan Maintenance (PM)

Bagian Produksi dan Maintenance (PM) dalam menggunakan SAP R/3 pada modul Quality Management (QM) yaitu untuk melihat jumlah dan karakteristik barang yang harus diproduksi. Bagian ini juga menggunakan SAP $R / 3$ untuk memeriksa ketersediaan bahan baku, apabila bahan baku yang dibutuhkan kosong, user bagian panel preparation akan memasukkan permintaan bahan baku ke sistem SAP R/3 untuk diteruskan ke bagian Pembelian.

4. Penerapan ERP pada Bagian Personalia dan Umum

Bagian Personalia dan Umum dalam menggunakan SAP R/3 pada modul Production Planning (PP) Melakukan Pengawasan terhadap penggunaan data, barang dan peralatan pada masing-masing departemen. serta mengkoordinir dan mengawasi pelaksanaan tugas dari kepala-kepala bagian. 
5. Penerapan ERP pada Bagian Accounting dan Finance

Bagian Accounting dan Finance Accounting menggunakan SAP R/3 pada Modul Controlling (CO), Enterprise Controlling (EC), Investment Management (IM), Treasury (TR) yaitu untuk memverifikasi dan melaporkan pengeluran dan penerimaan kas, membuat rekonsiliasi stock opname, memantau pergerakan harga dari bahan baku yang tersedia, dan mengumpulkan dokumen-dokumen terkait pembelian bahan baku dan penjualan. Bagian accounting menggunakan modul controlling untuk membuat cost center, product costing, internal order, profit center accounting, dan profitability analysis

6. Penerapan ERP pada Bagian Pembelian

Bagian Pembelian menggunakan sistem SAP R/3 pada modul General Logistics (LO) yaitu untuk memeriksa data persediaan bahan baku, apabila bahan baku kosong ketika diperlukan, bagian pembelian akan melakukan pembelian bahan baku. Di beberapa bahan baku, pembelian bisa langsung dilakukan dengan memesan kepada vendor bahan baku yang sudah bekerja sama dengan perusahaan

7. Penerapan ERP pada Bagian Divisi/Supervisor

Bagian Bagian Divisi/Supervisor dalam menggunakan SAP R/3 pada modul Sales and Distribution (SD) yaitu Melakukan Pengendalian kegiatan dibidang produksi, Menyiapkan laporan yang dibutuhkan Manager Produksi mengenai data produksi, jumlah batch produksi, pemakaian bahan dan lain-lain, serta Menyusun jadwal dan rotasi kerja bagi karyawan produksi yang dipimpinnya.

8. Penerapan ERP pada Bagian Gudang

Bagian gudang dalam menggunakan SAP R/3 pada modul Warehouse Management (WM) yaitu untuk melakukan stock opname, transfer barang dari satu gudang ke gudang yang lain, penerimaan barang dari vendor, ataupun mencatat penerimaan barang dari produksi. Dengan modul tersebut, perusahaan dapat mempersiapkan stock opname material yang beraneka ragam dengan baik.

\subsection{Describing, Classifying, Interpreting}

Pada bagian ini peneliti mendeskripsikan kekurangan dan keunggulan dari penerapan ERP di PT. Sinar Sosro. Kekurangan dari penerapan ERP adalah:

1. Hardware yang tidak dapat di-upgrade karena sistem ERP tidak bisa digunakan pada hardware yang baru.

2. Waktu proses data dari SAP R/3 yang ada di PT. Sinar Sosro sangat lama karena kapasitas server yang ada sudah tidak memadai.

3. Dengan sistem integrasinya yang menghubungkan proses bisnis perusahaan dari hulu menuju hilir, kesalahan entry data di awal proses SAP R/3 akan menyebabkan proses selanjutnya terganggu sehingga mempengaruhi semua proses bisnis PT. Sinar Sosro.

4. Jika program mengalami crash atau error process, pekerjaan bagian yang menggunakan Sistem ERP pun ikut terhenti.

Keunggulan dari penerapan ERP atau SAP R/3 di PT. Sinar Sosro adalah:

1. SAP R/3 mampu mengintegrasikan seluruh data yang digunakan dalam proses bisnis PT. Sinar Sosro antar tiap-tiap bagian.

2. PT. Sinar Sosro menjadi perusahaan yang peduli lingkungan karena penggunaan kertas yang sedikit di perusahaannya. 
3. Efisiensi waktu kerja karyawan dapat terealisasikan.

4. Meningkatkan efisiensi dalam proses bisnis misalnya dalam fungsi akuntansi yaitu mempermudah dalam tutup buku.

5. Penyeragaman kebijakan diantara semua unit bisnis perusahaan

\subsection{Representing, Visualizing}

Berdasarkan kelemahan dan kekurangan yang telah dipaparkan, maka peneliti memberikan usulan pemecahan masalah sistem ERP di PT. Sinar Sosro, yaitu:

1. PT. Sinar Sosro sebaiknya menginvestasikan kembali dananya untuk memperbarui sistem ERP yang digunakan.

2. Sistem ERP yang diperbarui akan secara otomatis mewajibkan di PT. Sinar Sosro meng-upgrade kemampuan hardware-nya dengan komponen terbaru dan lebih canggih.

3. Bagian TI bisa mengelompokan data-data yang tidak terpakai lagi kemudian menghapusnya atau menyimpannya ke dalam tempat penyimpanan yang tidak berhubungan dengan sistem ERP yang digunakan.

4. di PT. Sinar Sosro sebaiknya meningkatkan pengawasan terhadap entry data yang dilakukan user, sehingga ketika terjadi kesalahan entry, user dapat segera memperbaikinya sebelum data berjalan terlalu jauh.

5. Bagian TI dan BPO harus lebih responsif dalam menanggapi permasalahan sistem yang ada.

6. di PT. Sinar Sosro sebaiknya mengoptimalkan penggunaan sistem SAP R/3 di bagian yang sangat cocok, seperti bagian finance dan accounting.

\subsection{Proposisi}

Proposisi dari penelitian yang telah dilakukan adalah jika sistem ERP yang dimiliki PT. Sinar Sosro beroperasi dengan baik, ditandai oleh:

1. Terjadinya integrasi data antar bagian dalam proses bisnis PT. Sinar Sosro

2. Biaya operasional perusahaan menjadi lebih efisien

3. Efektifnya waktu kerja karyawan

4. Perbaikan pengolahan database perusahaan. maka penerapan ERP pada PT. Sinar Sosro dapat berjalan efektif dan efesien.

\section{Kesimpulan}

Berdasarkan uraian hasil dan pembahasan yang telah dijelaskan pada bab-bab sebelumnya. Maka penulis menarik beberapa kesimpulan yaitu :

1. Berdasarkan hasil analisis informasi yang didapat bisa ditarik kesimpulan bahwa Secara garis besar penerapan ERP pada PT. Sinar Sosro telah berjalan dengan baik, hal ini dapat dilihat dari terjadinya integrasi data yang terjadi pada PT. Sinar Sosro sehingga mempermudah perusahaan dalam pengambilan keputusan bisnis, dikarenakan data yang selalu terupdate, akurat dan konsisten.

2. Dengan Penerapan ERP Penjadwalan dapat teratasi sehingga masalah persedian dapat teratasi karena semua data terdokumentasi dengan baik, selain itu dapat meningkatkan efisiensi dalam proses bisnis terutama dalam fungsi akuntansi yaitu mempermudah dalam tutup buku. 


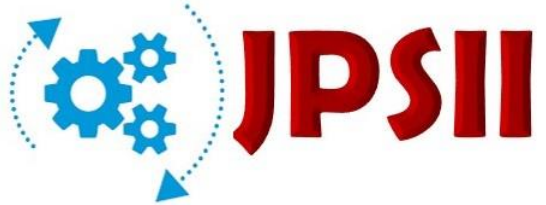

\section{Referensi}

Antoni, D., Herdiansyah, M. I., Akbar, M., \& Sumitro, A. (2021). Pengembangan Infrastruktur Jaringan Untuk Meningkatkan Pelayanan Publik di Kota Palembang. JURNAL MEDIA INFORMATIKA BUDIDARMA, 5(4), 1652-1659.

Antoni, D., Jie, F., \& Abareshi, A. (2020). Critical factors in information technology capability for enhancing firm's environmental performance: case of Indonesian ICT sector. International Journal of Agile Systems and Management, 13(2), 159-181.

Antoni, D., \& Akbar, M. (2019). E-supply chain management value concept for the palm oil industry. Jurnal Sistem Informasi, 15(2), 15-29.

Antoni, D., Fikari, D., \& Akbar, M. (2018). The readiness of palm oil industry in enterprise resource planning. Telkomnika, 16(6), 2692-2702.

Fauzi, F., Dencik, A. B., \& Asiati, D. I. (2019). Metodologi Penelitian untuk manajemen dan akuntansi. Jakarta: Salemba Empat.

(Indonesia et al. 2009; Linarwati, Fathoni, and Minarsih 2016; Nofri, Rispianda, and Liansari 2015; Prasanti 2018; Putra 2018; Subandi 2011; Tanto, Wing, and M 2015; Wibisono 2005)

Indonesia, Universitas et al. 2009. “Analisis Penerapan Enterprise Resource Planning Pada Pt Jotun Indonesia."

Linarwati, Mega, Azis Fathoni, and Maria M Minarsih. 2016. "Studi Deskriptif Pelatihan Dan Pengembangan Sumberdaya Manusia Serta Penggunaan Metode Behavioral Event Interview Dalam Merekrut Karyawan Baru Di Bank Mega Cabang Kudus.” Journal of Management 2(2): 1.

Nofri, Tania Rama, Rispianda, and Gita Permata Liansari. 2015. "Rancangan Implementasi Enterprise Resource Planning (ERP) PT World Yamatex Spinning Mills Bandung Menggunakan Openbravo.” Jurnal Online Institut Teknologi Nasional 03(01): 12.

O'LEARY, DANIEL E. (2000). "ENTERPRISE RESOURCE PLANNING SYSTEM", CAMBRIGE UNIVERSITY PRESS, USA.

Prasanti, Ditha. 2018. "Model - Model Penelitian Tindakan Kelas." Jurnal Ilmu Komunikasi 6(1): 13-21.

Putra, Rezi Eka. 2018. "Pengaruh Critical Success Dalam Implementasi Enterprise Resource Planning (ERP) Terhadap Kinerja Perusahaan Studi Pada PT. Angkasa Pura II (Persero)." Akuntabilitas 11(2): 381-94.

Subandi. 2011. "Qualitative Description as One Method in Performing Arts Study." Harmonia (19): 173-79.

Tanto, Winarno Wahyu Wing, and Arif Rudianto M. 2015. “Analisis Penerapan Sistem Enterprise Resource Planning Pada PT. Aneka Dharma Persada Di Yogyakarta.” Jurnal Telematika 8(2): 41-54.

Wibisono, Setyawan. 2005. "Enterprise Resource Palnning (ERP) Solusi Sistem Informasi Terintegrasi." Jurnal Teknologi Informasi Dinamik X(3): 123088. 


\section{Copyrights}

Copyright for this article is retained by the author(s), with first publication rights granted to the journal.

This is an open-access article distributed under the terms and conditions of the Creative Commons Attribution license (http://creativecommons.org/licenses/by/4.0/) 